IZA DP No. 5255

Mentoring, Educational Services, and Incentives to Learn: What Do We Know About Them?

Núria Rodríguez-Planas

October 2010 


\title{
Mentoring, Educational Services, and Incentives to Learn: What Do We Know About Them?
}

\author{
Núria Rodríguez-Planas \\ Universitat Autònoma de Barcelona, \\ MOVE, FEDEA and IZA
}

\section{Discussion Paper No. 5255 \\ October 2010}

\author{
IZA \\ P.O. Box 7240 \\ 53072 Bonn \\ Germany \\ Phone: +49-228-3894-0 \\ Fax: +49-228-3894-180 \\ E-mail: iza@iza.org
}

Any opinions expressed here are those of the author(s) and not those of IZA. Research published in this series may include views on policy, but the institute itself takes no institutional policy positions.

The Institute for the Study of Labor (IZA) in Bonn is a local and virtual international research center and a place of communication between science, politics and business. IZA is an independent nonprofit organization supported by Deutsche Post Foundation. The center is associated with the University of Bonn and offers a stimulating research environment through its international network, workshops and conferences, data service, project support, research visits and doctoral program. IZA engages in (i) original and internationally competitive research in all fields of labor economics, (ii) development of policy concepts, and (iii) dissemination of research results and concepts to the interested public.

IZA Discussion Papers often represent preliminary work and are circulated to encourage discussion. Citation of such a paper should account for its provisional character. A revised version may be available directly from the author. 
IZA Discussion Paper No. 5255

October 2010

\section{ABSTRACT \\ Mentoring, Educational Services, and Incentives to Learn: What Do We Know About Them?*}

This paper reviews recent studies on the effectiveness of services and incentives offered to disadvantaged youth. We focus our analysis on three types of interventions: mentoring, educational services, and financial rewards. The objective of this article is threefold. First, we explain alternative theoretical points of view in favor (or against - when applicable) each of these interventions. Then, we discuss how recent empirical work has affected that view, and we summarize the latest findings. We conclude with a discussion on what questions remain to be examined. Our hope is that this article will serve as a resource for those seeking to understand what educational interventions work and for whom, and to use as a starting point to illuminate the debate on where to go next.

JEL Classification: C93, I21, I22, I28, J24

Keywords: cognitive and non-cognitive skills, intrinsic and extrinsic motivation, at-risk youth, resilience, deviancy training, deterrence, primary- and high-school, post-secondary education, remedial programs, incentives on inputs and outputs

Corresponding author:

Núria Rodríguez-Planas

Unitat de Fonaments de l'Anàlisi Econòmica

Edifici B

Universitat Autònoma de Barcelona

08193 Bellaterra

Spain

E-mail: Nuria.Rodriguez@uab.es

\footnotetext{
* Núria Rodríguez-Planas acknowledges financial support from the Spanish ministry of Education and Science (grant SEJ2006-712), the Generalitat de Catalunya (grant SGR2005-712), and Barcelona Economics XREA - Program. Finally, Núria Rodríguez-Planas is affiliated to IZA in Bonn, FEDEA in Madrid, and Graduate School of Economics and MOVE in Barcelona, and greatly appreciates their support.
} 


\section{Introduction}

In response to the observed increasing earnings differential between the most and the least educated workers since the late 1970s, policies aiming at improving high-school graduation and post-secondary education enrollment have recently received renewed attention from policy makers, practitioners and researchers. As a consequence, there has been a new wave of interventions whose main objective is to improve the school performance of disadvantaged youth. Most of these interventions involve one or the combination of the following services: (i) a mentoring component; (ii) an educational component; and (iii) a financial incentive component. Reviewing the theoretical motivation and the empirical evidence of these three interventions is the main focus of this paper.

The objective of this article is threefold. First, we explain the alternative theoretical points of view in favor (or against-when applicable) each of these interventions. Then, we discuss how recent empirical work has affected that view, and summarize the latest findings. Finally, we conclude with a discussion on what questions remain to be examined. The paper also presents the evidence on gender differential effects.

The paper focuses on recent studies that use either experimental design or quasiexperimental design approaches, choosing to exclude those studies that do not provide a control group (or a rigorous comparison group). To reduce the overlap with the extended literature on the effectiveness of interventions aimed at youth, we narrow most of the review to studies recently conducted — that is, within the last decade. Three main findings arise. First, rigorous evidence on mentoring programs finds positive but modest effects on the young people that participate in them, and that the most disadvantaged or at-risk seem to benefit the most from them. However, there are concerns (and evidence) that these programs sometimes backfire. Second, studies on the effectiveness of educational services find that the earlier the intervention the better. Nonetheless, a couple of recent studies have found that interventions at the high- 
school or post-secondary education level work quite effectively for females when combined with financial incentives and mentoring. Third, the evidence on financial rewards is mixed. While some studies find that they work in the short-run for certain subgroups, the difficulty in replicating those results suggests that the impact of incentives is context dependent.

A number of previous papers review the effectiveness of: (i) mentoring programs from the psychologist perspective (DuBois et al., 2002; Jekielek et al., 2002; Rhodes, 2008; Toland et al., 2008); (ii) input-based schooling policies—such as lowering class sizes or tightening the requirement for teaching credentials-(Hanushek, 2003; and Rockoff, 2009); (iii) interventions on human capital skill formation (Heckman, 2000; and Cunha, et al., 2006); (iv) early childhood education programs (Heckman, 2000; Currie, 2001); (v) training and employment programs (Lalonde, 1995; Heckman et al., 1998; and Heckman, 2000); or (v) financial incentives in laboratory experiments (Camerer and Hogarth, 1999; Bonner et al., 1996; Herwig and Ortmann, 1998; and Jenkins et al., 1998). Our hope is that this article will serve as a resource for those seeking to understand what educational interventions work and to use as a starting point to illuminate the debate on where to go next.

\section{Mentoring}

\section{A. Theoretical Motivation}

Frequently, the problem with academic failure is not necessarily due to the students’ lack of cognitive skills, but instead due to (i) weak non-cognitive skills; ${ }^{1}$ or (ii) personal, family, and social barriers that interfere with youth's ability to attend school and do well there (Finn, 1989). ${ }^{2}$ From psychologists' perspective, building strong positive relationships with extra familial adults (mentors) promotes resiliency among at-risk youth because mentoring

\footnotetext{
${ }^{1}$ By non-cognitive skills I refer to self-esteem, motivation, tenacity, trustworthiness, and perseverance.

${ }^{2}$ Examples of personal, family or social barriers are being a teenage mother, not having a family car (or unavailability of parents to drive students to school), being hungry, or having some drug abuse problem, among others.
} 
facilitates adolescents' capacity to benefit from the support of parents and other providers, and influences positively the youths' perceptions of self-worth and their beliefs about their competence as learners and their valuing of school (Rhodes et al., 2000). Similarly, a willingness of adults (outside the family) to discipline youths, provide positive role models, and reduce the amounts of unsupervised youth activity are hypothesized to reduce crime (Wilson, 1987). According to this view, the effects of mentoring ought to be stronger on younger youth and those more at-risk. This is so because younger children are more malleable and receptive than older ones, implying that activities aiming to improve their social and emotional skills ought to have a greater impact the sooner they are imparted to the child and the improved environment (Heckman, 2000; Currie, 2001). The mentoring view also expects greater gains among the most “at-risk" by virtue of individual or environmental circumstances because they are those for whom mentoring can make more of a difference in terms of emotional development (Rhodes, 1994; Hall, 2003). Finally, when strong personal relationships are built, the long-term positive effects of these relationships ought to be long lasting since the benefits from socialization and the integration into mainstream society will foster further personal and emotional development.

\section{B. Empirical Evidence}

Rigorous studies on the effectiveness of mentoring programs find that they have positive but modest effects on (some of) the young people that participate in them, and that the most disadvantaged or at-risk seem to benefit the most from them-see Dubois et al., 2002; Jekielek et al., 2002; and Rhodes, 2008 for thorough reviews on the effectiveness of mentoring programs; and Grossman and Tierney, 1998, for a random assignment evaluation of one of the most well known mentoring program in the United States: Big Brother/Big Sister (BBBS). However, some of these studies reveal that, even when positive effects are 
found, they do not necessarily translate into higher academic performance. For instance, a recent experimental evaluation of a school-based mentoring program (the Study of Mentoring in the Learning Environment (SMILE)) finds small, positive effects of mentoring on students' connectedness to peers and on self-esteem and social skills, but not on academic outcomes (Karcher, 2008).

Despite the large evaluation literature on effectiveness of youth mentoring programs - which includes reviews, program evaluations, and meta-analyses - , the bottom line is that not enough is known, or as Roberts et al., 2004 put it "robust research does indicate benefits from mentoring for some young people, in some circumstances, in relation to some outcomes.” Moreover, Rhodes, 2008, calls for cautious optimism about the potential viability of mentoring interventions as results vary considerably depending on the characteristic of the individuals involved and the quality of the relationships they form. Indeed secondary analysis of both school- and community-based BBBS showed differential outcomes depending on the quality of the mentoring relationships with bigger benefits for those in stronger relationships, and neutral or even negative outcomes for those with less effective mentoring relationships (Herrera et al., 2007; and Grossman and Rhodes, 2002).

According to DuBois et al., 2002, important elements leading to beneficial outcomes of mentoring programs include: (i) providing adequate support and structure for mentoring relations throughout the formative strategies of their development; (ii) having relatively strong relationships between mentors and youths in terms of frequency of contact, emotional closeness, and longetivity; and (iii) targeting those youth considered most at-risk on the basis of environmental-level characteristics or both individual and environmental perspective,- - but not those youth identified as being at risk solely on the basis of individual-level characteristics (such as, academic failure) since little benefits from mentoring have been identified for such group. 
Although DuBois et al.'s meta-analysis concludes that there is some limited evidence that benefits from mentoring extend beyond the end of the program participation, Rhodes, 2008, warns that beneficial effects of mentoring programs (when found) erode to nonsignificance within only a few months of program participation. In particular, some recent studies corroborate Rhodes' remark on the longetivity of the beneficial outcomes. For instance, Herrera et al., 2007, find that the beneficial results from the school-based BBBS programs (such as, improved students' academic performance, behavior in school, and school attendance) did not endure into the following school year. Similarly, two experimental studies of the Across Ages mentoring program found that encouraging outcomes (such as, lower levels of student substance use and problem behaviors, and stronger attachment of students to school and their families) were not sustained beyond the end of the school year (Taylor, LoSciuto, Foz, and Sonkowsko, 1999; and Aseltine, et al., 2000).

Another challenge in this literature is to understand the mechanisms through which mentoring works and affects academic outcomes. Using the BBBS data, Rhodes et al., 2000, test whether the effects of mentoring on youths' academic outcomes are mediated through improved parental relationships versus scholastic competence, school value, and self-worth. Their results validate the hypothesis that improved perceptions of parental relationships, although not the sole determinant, are important mediators of change in adolescents' academic outcomes and behaviors. These results are consistent with other findings on the relevance of parents’ involvement in early childhood interventions (Currie, 2001). 


\section{Alternative Explanations for Unanticipated Negative Effects of Mentoring}

Frequently, the purpose of mentors is to assess both the unmet needs of at-risk youths and the barriers they face and to facilitate access to a service mix that best addresses their needs and barriers. However, it may well be that mentors end up overprotecting youths in such a way that they reduced their costs of engaging in risky behaviors (in particular, but not exclusively, criminal activity). For instance, by acting as advocates of youths and negotiating on behalf of them with the high school, the criminal justice and other public agencies when youth get in trouble, mentors may mitigate the consequences of misbehaving. And by doing so, they may have a perverse effect in that they prevent its mentorees from internalizing the full costs of engaging in such types of risky behaviors, leading to higher involvement in such type of activities in the future. This view is consistent with Becker's 1968 economic model of crime in which crime can be deterred through punishment, and with studies that have found that youths are responsive to sanctions (see for instance, Pacula et al., 2001; Chaloupka and Saffer, 1999; Levitt, 1998; and Levitt and Lochner, 2001, among others).

Rodríguez-Planas, 2010, finds evidence supporting this hypothesis of deterrence (that is, a behavioral response of potential deviants to the incentives they face) using a randomized experiment of an intensive and comprehensive mentoring after-school program that lasted for five years - the four years of high-school plus one additional year in case youths fell behind a grade-, and that was targeted to at-risk youths in the United States: The Quantum Opportunity Program. The author finds that, at the end of the intervention when youths were in their late-teens, program enrollees were significantly more likely to report having participated in a program that help them stay out of trouble and deal with police and the judicial system than members in the control group. However, five years later when youths 
were in their mid-twenties, male enrollees were more likely to report committing a crime and being arrested or charged than males in the control group. ${ }^{3}$

This is not the only intervention to find no beneficial effects or unanticipated negative effects on participants. The well-known randomized, experimental trial of the communitybased treatment program Cambridge-Somerville Youth Study, whose objective was to prevent delinquency, found that youths in the treatment group were more likely to be rearrested for crimes and have other negative impacts on physical and psychological health compared to youths in the control group in the long-run (McCord, 1978 and 1992). The intervention was targeted to boys ages 5 to 13, and children in the treatment group received an individual counselor who visited the family around twice a month for five years and were referred to or received services in a variety of areas: tutoring, medical, psychiatric, summer camps, Boy Scouts, YMCA, or other community programs. In contrast, children in the control condition did not receive any referrals or visits from a counselor. The impacts were measured up to 30 years later using official state records.

More recently, the experimental evaluation of the Student Mentoring Program, which was designed to fund grantees to enable them to provide mentoring to at-risk students in grades 48, and whose ultimate goal of the program was to improve student academic and behavioral outcomes through the guidance and encouragement of a volunteer mentor, found that the program had no statistically significant impacts on any of the 17 outcomes measured, which covered academic achievement and engagement, interpersonal relationships and personal responsibility, and high-risk or delinquent behavior (Bernstein, et al., 2009). Similarly, a

\footnotetext{
${ }^{3}$ The results from this demonstration contrast with those from the evaluation of a pilot of the program conducted several years earlier (Hahn, 1999; Hahn et al., 1999). While the results from the QOP pilot were slightly more promising than those from the large-scale evaluation demonstration discussed in this paper, they were measured at most several months after participants should have graduated from high-school, and therefore it is unclear whether these findings would have persisted over time as youth grew older. Other important differences between the pilot and the demonstration included the sample size, which was smaller in the pilot, and the targeted population, which, in the pilot, were low-income students (as opposed to academically lowperforming students as in the demonstration). Finally, results from the pilot were frequently driven by one site.
} 
different type of intervention that also aimed at improving non-cognitive skills, has also found discouraging results (Holmlund and Silva, 2009). Although in this case, the authors present convincing evidence that unobservables may be biasing these results. Using a quasiexperimental design, the study evaluates the effects of a two-year intervention that targeted 14 years old at-risk youths’ non-cognitive skills—such as, self-confidence, locus of control, self-esteem and motivation-with the aim of improving students' records of attendance, test scores, and end-of-compulsory-education (age 16) cognitive outcomes. The cross-sectional quasi-experimental estimates of the effect of the policy show a negative and significant impact on treated youths' test scores at age 16, however, difference-in-differences and double-differences estimates suggest that negative selection into the program based on youth's unobservables may be biasing these results.

In addition to the hypothesis of deterrence, other explanations may also lead to mentoring programs having a perverse effect on youths’ outcomes. For instance, it may well be that by offering a mentor, the program may weakened the ties between enrollees and their parents, breaking important social bonds. An alternative and related explanation is that because enrollees' parents trusted that another adult (the mentor) was also watching over their children, they ended up investing less time with their children and paying less attention to possible warning signs than parents of youths in the control group. In essence, the program may have led to a substitution effect away from parents' attention, which could have explained these detrimental findings. Yet another hypothesis for the perverse results is that the program may have led its enrollees to be more aware of their relative disadvantaged situation in life, which may have brought upon them further disappointment, leading them to engage in diverse types of risky behaviors.

Another explanation for unexpected negative effects is that the anticipated positive effects of mentoring programs were off-set by simultaneous negative effects due to "deviancy 
training," which occurs when peers reinforce deviant conduct by responding with approval and attention (this would specially apply to mentoring programs where the mentor is assigned to work with several mentorees at the same time). Dishion and colleagues have shown that increased exposure to negative peer influences via deviancy training is associated with increased substance use, delinquency, and violence (Dishion, et al., 1999; Dishion, et al., 1996; and Patterson, et al., 2000). Furthermore, it is possible that interventions serving highrisk students will generate a greater deviancy training effect as the population is more likely to actively model and encourage deviance. Indeed, research suggests that grouping high-risk youths together for intervention services can increase subsequent delinquency (Cho, et al., 2005; and Dishion, et al., 1999).

Finally, Rhodes, 2002, speculates about the possibility of unintentional negative effects of mentoring, particularly in cases where mentoring relationships are disrupted or terminated. In his rigorous experimental evaluation, Karcher, 2008, found negative effects of schoolbased mentoring on cooperation of high-school-aged boys that is consistent with this possibility.

\section{Human Capital Theory}

\section{A. Theoretical Motivation}

The lack of academic preparation or poor study skills represents a major challenge for many teenagers' academic success and high-school completion. To improve their school performance and prevent them from dropping out of high-school, there are many academic support services offered to low-achieving at-risk youth based on the premise that augmenting instruction time ought to increase the students' cognitive skills and help them get back on track. $^{4}$ Just as in the case for mentoring programs (but for different reasons), the human

\footnotetext{
${ }^{4}$ Academic services take various forms, such as remedial instruction, summers schools, computer-assisted
} 
capital theory predicts that the younger the individual the stronger the effect of the educational program. This is because younger individuals have a longer time to recoup their investment than older ones, for the same level of investment at each age, implying that the return to human capital will be higher for the former than the latter (Becker, 1964). However, in contrast with the mentoring view, the human capital model predicts a stronger effect of an educational program on the higher ability youth. This is so because human capital has a fundamental dynamic complementarity feature that implies that skills acquired early on make later learning easier (Heckman, et al., 1998; and Heckman, 2000).

Whether the effects of academic support services are long-lived will depend on the nature of the knowledge acquired. A priori, the human capital model predicts that the learning ought to be long-lived. However, the improvement in knowledge will be short-lived if: (i) the learning is transitory_- “declarative knowledge” (facts about the world) are much more likely to be quickly and subsequently forgotten than "procedural knowledge" (a repertoire of skills, rules and strategies for using declarative knowledge to solve problems); (ii) the learning is mechanical-for instance, it mainly involves improvement in test-taking techniques; or (iii) there is a Hawthorne effect—i.e., individuals do not learn but it seems like it because they improve their test performance due to an increase in effort and attention caused by their gratefulness towards the services received. Alternatively, the acquired knowledge may also fade away overtime if there is no continuous reinforcement and the learning that occurred gets swamped by the churning that takes place as youth grow older.

\section{B. Empirical Evidence}

The results in this literature suggest that the earlier the intervention the better-consistent with many academics and practitioners' beliefs that early childhood interventions are preferred 
(Heckman, 2000; Currie, 2001; Currie and Thomas, 2001; Krueger and Whitmore, 2001; Carneiro and Heckman, 2003, and Cunha, et al., 2006). Two recent studies evaluating various educational services offered to primary school children- Jacob and Lefgren, 2004, and Banerjee et al., 2007—, find beneficial longer-term effects, one or two years after the end of the program. Using a regression discontinuity design, Jacob and Lefgren, 2004, examine the causal effect of summer school and grade retention on student achievement. Contrary to conventional wisdom and prior research, the authors find that the net effect of attending summer school was to substantially increase academic achievement among third graders, but not sixth graders. Banerjee et al., 2007, evaluate two randomized evaluations in India. The first offered basic literacy and numeracy skills to students who had reached third and fourth grades without mastering them. The second offered computer-assisted math training to all four-grade children two hours per week. The authors find that the remedial education program increased average test scores of all children in the treatment schools, mostly due to large gains experienced by children at the bottom of the test-score distribution; and that the computer-assisted learning program increased math test scores. The authors find that, despite fading a bit, the initial gains remained significant one year after the end of the program.

In contrast with these encouraging findings, James-Burdumy et al., 2008, conduct a randomly design evaluation of the after-school program, $21^{\text {st }}$ Century, offered to elementary students. These authors find that the program: (i) reduced parent-care after school, (ii) increased care by other adults after school, (iii) improved feelings of safety after school, (iv) had no impact on academic achievement as measured by reading test scores or grades, and $(v)$ led to higher levels of negative behavior among the treatment group relative to the control group on multiple outcomes, including suspensions, teachers calling students' parents about behavior, and students being disciplined by teachers. According to the authors possible explanations for these results are lack of coordination with school-day curriculum and teachers, or long days for elementary 
children leading fatigue or negative behavior.

The encouraging results from early childhood interventions also contrast with findings from service-oriented dropout-prevention programs that are implemented during the high-school years. Dynarski and Gleason, 2002, summarize findings from a large evaluation of United States' federally funded dropout-prevention programs and find that, although intensive interventions at middle-school level can keep students in school longer, or even accelerate their progress in school, they have no effects on attendance or academic performance. Moreover, when analyzing dropout-prevention programs for students of high-school age, these authors find that these programs did not succeed in lowering dropout rates, although they did increase highschool diplomas instead of GED certificates. These authors also highlight that these program work best when the educational services are combined with mentoring

In contrast with these discouraging studies, three recent rigorous studies have found positive returns for interventions offering educational services targeted to youth at a relatively late stage of schooling (Machin, et al., 2004; and Lavy and Schlosser, 2005; and Rodríguez-Planas, 2010). While Machin, et al., 2004; and Lavy and Schlosser, 2005, use a quasi-experimental design, and focus on short-term impacts of the educational services offered to high-school students in Israel and the United Kingdom, respectively; Rodríguez-Planas, 2010, uses an experimental design to evaluate the short-, medium-, and longer-term impacts of the Quantum Opportunity Program, an intensive mentoring program offering educational services and financial incentives for 5 years to at-risk youth in the United States. As it was, the average amount of time (708 hours) enrollees spent on educational activities during the first four years of the Quantum Opportunity Program corresponds to about $72 \%$ of an extra school year, a substantial investment of time (in addition to the time spent with the mentor). Machin et al., 2004, evaluate the Excellence in Cities (EiC) program, which aims at alleviating poor students' achievement in inner city areas. Using a difference-in-difference approach, the authors find small but positive improvement in pupil 
attainment and strong reduction in absences within EiC schools relative to schools in the comparison group. Using the same methodology, Lavy and Schlosser, 2005, study the effect of targeted remedial education on underperforming teenagers in Israel, and find that it increased the probability of earning a matriculation certificate, but had no effects on achievement (although they did find that program participants gained on average two additional credits without lowering their average score). While Rodríguez-Planas, 2010, finds similar short-term hefty beneficial average impacts on high-school graduation and post-secondary education enrollment, she finds that these encouraging results quickly faded away as some control group members eventually caught up to the treatment group. Moreover, heterogeneity mattered as the program fared significantly better in multiple dimensions for its female than its male enrollees. ${ }^{5}$

Finally, results from evaluations on post-secondary academic support services are mixed. On the one hand, Bettinger and Long, 2009, and Scrivener et al., 2008, found academic performance improvements of remediation programs; on the other, Angrist et al., 2009, found that academic support services worked for college freshmen women in Canada only when combined with peer advising and financial services are combined. Using variation in remedial placement policies across institutions and the importance of proximity in college choice and data from 28,000 students, Bettinger and Long, 2009, examine the effects of math and English remediation on college students from Ohio. Their findings suggest that students in remediation are more likely to persist in college in comparison to students with similar test scores and backgrounds who were not required to take the courses. They are also more likely to transfer to a higher-level college and to complete a bachelor's degree. Using an randomized experiment design, Scrivener et al., 2008, analyze the effects of learning communities, which placed college freshmen in groups of up to 25 who took three classes

\footnotetext{
${ }^{5}$ Using quasi-experimental methods, Pema and Mehay, 2009, study the impact of the Junior Reserve Officers' Training Corps (JROTC), a program that combines classroom instruction, with more broad extra-curriculum activities — such as physical education, military drill and customs, community service activities, and summer camp. The evidence of the program on high-school students' education and labour market outcomes is mixed.
} 
together during their first semester and provided enhanced counseling and tutoring as well as a voucher for textbooks. Two years after implementation, the authors find promising cognitive and non-cognitive results. For instance, they find treated students attempted and passed more courses and earned more credits during their first semester (although, these effects diminished in subsequent semesters). Moreover, they find that the program moved students more quickly through developmental English requirements, and that students in the program group felt more integrated and more engaged than students in the control group. Angrist et al., 2009, is the only study that evaluates three types of treatment (one involving financial rewards, another one involving educational services, and the third one combining the other two) on grades and academic standing of college students in Canada using an experimental design, and they find no effects of educational services when implemented alone. However, these authors did find long-lasting beneficial effects on academic achievement for women when the educational services were combined both with mentoring and financial awards based on grades—of $\$ 5,000$ in cash, almost exactly the same as a year's tuition, for a grade average of B (a GPA of 3.0) or higher, or $\$ 1,000$ in cash for a C+ or B- (a GPA of 2.3 to 2.9).

\section{Financial Incentives Awards}

\section{A. Theoretical Motivation}

Students may exert suboptimal study effort if they overly discount the future (Greene, 1986; Nurmi, 1991, Gruber, 2001), if they have time inconsistent preferences, such as hyperbolic discounting (Green et al., 1994; Kirby, 1997; Laibson, 1997, Bettinger and Slonim, 2007), or if they perceive overly high education costs or overly low expected returns (Eckstein and Wolpin, 1999). In such cases, standard economic models predict that financial incentives ought to increase individual study effort and improve performance under the assumption that 
performance is positively related with effort (Smith and Walkers, 1993; Gibbons, 1997; and Lazear, 2000). Similarly, behaviorist psychology also predicts that rewards improve performance, albeit for different reasons, namely financial reward offered for an unpleasant activity will reduce the aversion towards that activity, leading to long-run positive effects on performance (Skinner, 1953). According to these theories, the effects of financial rewards ought to be long-lived, especially if they create a studying habit behavior, if they reduce distaste for studying, or if they increase human capital (and therefore lower the subsequent education costs).

However, the positive effect of financial rewards on behavior has been seriously questioned both in economics and psychology. The economists' argument is that this prediction may fail because factors other than money and effort may enter into the decision of the agent. Such factors include the signaling consequences of accepting very small compensations for a task, social norms that prescribe a behavior independently of financial rewards, or reciprocity, among others (see Titmuss, 1970, and 1971; Frey, 1994; Frey and Oberholzer-Gee, 1997; Kohn, 1993, and Benabou and Tirole, 2003, among others). The cognitive psychology school also challenged the conclusion of behaviorist psychologists by arguing that financial rewards may replace powerful and enduring “intrinsic motivation” (the individual's desire to perform the task for its own sake) with short-lived "extrinsic motivation" that ultimately reduces effort and achievement (Kruglansky et al., 1973; Deci et al., 1973; Lepper and Greene, 1978; and Kohn, 1999). If so, we may observe that there are detrimental or no short-term effects of the financial rewards or that the initial positive effects are short-lived and quickly fade away. As in the standard economic theory models and the behaviorists’ psychology school, these theories predict that the cognitive skills of individuals (educational background, and general intelligence) may interact with incentives leading to better outcomes for better endowed (in terms of human capital, or ability) students (Camerer and Hogarth, 1999). However, in contrast with the earlier models, they do not predict positive long-run effects of the financial rewards, as weak 
reinforcers in the short term may have hidden costs, in that they become negative reinforcers once they are withdrawn.

\section{B. Empirical Evidence}

\section{Experimental and Field Laboratory Evidence}

While experimental psychology research supported the idea that reward-based incentives lead to increased effort in students (Holland and Skinner, 1961), a substantial body of experimental and field laboratory evidence conducted in the 1970s and later indicates that extrinsic motivation (contingent rewards) can sometimes conflict with intrinsic motivation (the individual's desire to perform the task for its own sake). For instance, Deci, 1975, found that those college students, who were not paid to work for a certain time on an interesting puzzle, played with the puzzle significantly more in a later unrewarded "free-time" period and reported a greater interest in the task than paid subjects. This experiment was replicated for high-school students in tasks involving verbal skills (Kruglanski, Friedman and Zeevi, 1971), and for preschool children in activities involving drawing with new materials (Lepper, Greene and Nisbett, 1973). More recently, Gneezy and Rustichini, 2000, found that students who were collecting donations doorto-door actually visited fewer houses and collected less money when they were paid a small commission. Other experiments finding that people who were not paid at all exerted greater effort than those who were paid a small amount include Wilson, Hull and Johnson, 1981; Kohn, 1993; Frey and Jegen, 2000; and Heyman and Ariely, 2004, among others. More recently, laboratory research attempting to quantify the effect of external factors on intrinsic motivation has yielded mixed conclusions: Cameron et al., 2001, conducted meta-studies of over 100 experiments and found that the negative effects of external rewards were limited and could be overcome in certain settings - such as for high-interest tasks - but in a similar meta-study Deci et al., 1999, concluded that there are often negative effects of rewards on task interest and 
satisfaction. $^{6}$

\section{Experimental and Quasi-Experimental Evaluations}

Despite this substantial laboratory and field experimental evidence, demonstrations offering students cash incentives are becoming popular among policy makers, practitioners and researchers, and they are being offered both in primary and secondary education in many countries. For instance, three high-schools are offering such types of incentives in Créteil, a suburb of Paris, France (El País, 2009). In the United States, the Education Innovation Laboratory at Harvard has implemented four evaluations offering financial rewards with the objective of improving academic performance of youth, such as Capital Gains in Washington DC, Spark and Million Motivation Campaign in New York, and The Paper Project in Chicago (Fryer, 2010). Other interventions involving incentive programs in primary and secondary education are also taking place in the Baltimore City Public School District (Ash, 2008); and in Texas (Jackson, 2007). Finally, other related international examples include Progresa in Mexico (Behrman et al., 2000; and Schultz, 2004), Familias en Acción program in Colombia (Attanasio et al., 2006), the Education Maintenance Allowance in the United Kingdom (Dearden, et al., 2005), a merit award program for girls in Kenya (Kremer et al., 2008), or cash incentives to low-performing schools in Israel for increasing their high-school matriculation certification rate (Angrist and Lavy, 2009)

There are two types of financial incentives offered to students: those on inputs and those on outputs. Incentives on outputs are more common in the student incentives literature. In most studies on student incentives the objective is to pass a test and students are paid if they complete the objective. As Fryer, 2010, explains, under certain assumptions, traditional price theory predicts that providing incentives based on output is socially optimal because each student decides which input from their production function to subsidize. Assuming that

\footnotetext{
${ }^{6}$ See Camerer and Hogarth, 1999; Bonner et al., 1996; Herwig and Ortmann, 1998; and Jenkins et al., 1998, for thorough reviews of the effects of financial incentives in experiments.
} 
students have superior knowledge about how they learn, it is socially optimal to allow them to allocate their time across inputs. However, if this assumption is violated, then it can be more effective to provide incentives for inputs.

The evidence on financial incentives is still mixed. Two recent studies on financial incentives on outputs have found encouraging results. Kremer et al., 2008, report results from a randomized evaluation of a merit scholarship program in Kenya in which girls who scored well on academic exams at the end of $6^{\text {th }}$ grade had their school fees paid and received a cash grant for school supplies over the next two years. In the sample as a whole, girls eligible for the scholarship showed substantial gains in academic exam scores, and teacher attendance also improved significantly in program schools. There was also evidence of positive externalities: girls with low pre-test scores, who were unlikely to win, showed test score gains in program schools. Angrist and Lavy, 2009, used a school-based randomization design targeted to low-performing schools offering cash incentives to all who passed their high-school matriculation certificate (Bagrut) in Israely treated schools. The experiment led to a substantial increase in certification rates for girls with high predicted Bagrut rates relative to other girls in the sample, that is, girls with a relatively high ex-ante chance of certification. ${ }^{7}$ However, they do not find any effect on boys, nor girls who were not as close to passing anyways. The authors also find beneficial lasting effects on college attendance among girls who were relatively close to success 5 years after the end of the program.

In contrast, Fryer, 2010, measures the effect of four different financial incentives on student achievement: two of them are "output" experiments (the ones in Chicago and New York city) and the other two (in Dallas and in Washington, DC) are "input” experiments, and only finds encouraging results for cash incentives on certain inputs. Indeed, he finds that incentives for output did not increase achievement, while incentives for certain inputs did

\footnotetext{
${ }^{7}$ Female matriculation rates increased partly because treated girls devoted extra time to exam preparation.
} 
(such as incentives for reading book, but they worked for certain groups only). He explains that the leading theory behind these findings is that students do not understand the educational production function and, thus, lack the know-how to translate their excitement about the incentive structure into measurable output. ${ }^{8}$

While some studies using a quasi-experimental approach find beneficial effects of financial rewards on academic performance (Ashworth et al., 2001; Dearden, et al., 2005; and Dynarski, 2003 and 2008), others find that scholarships lead students to get better grades but to take less ambitious course loads (Binder, et al., 2002; Cornwell et al., 2005; Cornwell et al., 2006). Similarly, Angrist et al., 2002, and Angrist et al., 2006, have also found that vouchers for private secondary school students conditional on their maintaining a satisfactory level of academic performance led to academic gains, one possible channel being the incentives associated with conditional renewal of scholarships. Using a regression discontinuity design, Garibaldi et al., 2007, find that gradually increasing tuition payments in response to delayed completion had substantial effects on Italian college women.

Two recent randomly designed studies have found that incentives work for women when combined with other services. As explained earlier, Angrist et al., 2009, find lasting improvements on grades and academic standing for college freshmen women in Canada only when educational services, peer advising and financial services are combined. Similarly, the Quantum Opportunity Program, which analyzes the effects of combining financial incentives (both on inputs and outputs) with mentoring and educational services, also finds that there were important gender differential effects of the program (Rodríguez-Planas, 2010). The financial incentives in this program had two components: an incentive on inputs and another

\footnotetext{
${ }^{8}$ A related literature to financial incentives on outputs includes numerous studies examining the impact of various types of tuition and financial aid policies on college-going show that students respond to changes in college cost (Leslie and Brinkman, 1988; Cornwell, Mustard, Cameron and Heckman, 1993; and Kane, 1998; Dynarski, 2003; and Deming and Dynarski, 2009). A consensus estimate associates a $\$ 1,000$ change in college costs with an approximately 5 percentage point difference in college enrollment rates. Moreover, according to a recent study by Kane, 2007, there would be differential effects by race, being stronger for African American.
} 
one on outputs. First, youth received a stipend of $\$ 1.25$ for every hour devoted explicitly to educational activities, developmental activities (excluding recreational activities), and community service. Second, a matching amount was promised to the youth when he or she earned a high school diploma or GED and enrolled in post-secondary education or training (including vocational training or military service). ${ }^{9}$ This was clearly an incentive on output as the student received the economic incentive only if they graduated from high-school and enrolled in post-secondary education. By the end of the demonstration, this represented for most youths receiving between $\$ 1,000$ to $\$ 3,000$ after high-school graduation and enrollment in post-secondary education, a far from negligible amount. The size of this incentive is comparable to the ones currently being offered in ongoing evaluations, such as, Capital Gains, where the average student will earn $\$ 750$ per year; Spark, where $7^{\text {th }}$ graders can earn up to $\$ 500$ per year; or The Paper Project, where the average student will earn $\$ 800$ per year (up to a maximum of $\$ 2,000$ per year). The program helped female students get them through high-school and post-secondary training (not necessarily college) quicker than their counterparts in the control group. Moreover, five years after the end of the program, female enrollees had better employment outcomes than control group members. In contrast, the program had some adverse short-term impacts on male students' academic performance and substance abuse, while leaving their rate of high-school graduation unaffected. Moreover, males showed worse adult employment outcomes and higher involvement on adult criminal activity than members of the control group. Unfortunately, the program was not designed to test for alternative channels, and thus, it is unclear which of the three components mattered the most for the beneficial results on women.

While Kremer et al., 2008, did not find evidence for weakened intrinsic motivation or gaming, and their effects persisted one year after incentives were removed, they also found

\footnotetext{
${ }^{9}$ This is a similar design to the one currently applied in The Paper Project, which rewards high-school students for core class grades, in that half of the reward is given to the student immediately, the other half is distributed at graduation.
} 
evidence of heterogeneity in program effects, suggesting the impact of incentives is context dependent. $^{10}$ Leuven et al., 2003, is the only real-world context study to find explicit evidence consistent with external rewards crowding out intrinsic motivation for the least able students both in the short-term and in the longer-run. They study the impacts of financial rewards on academic achievement of college students in Amsterdam and measure its effects up to three years after the end of the program. Unfortunately, their small sample sizes limit statistical precision, complicating inference. Leuven et al., 2003, find positive (negative) long lasting effects on academic achievement for the academically strong (weak) students.

\section{Sex Matters}

As is frequently found in the literature, results frequently differ by sex. Explanations for this differential impact include the fact that young women may have more self-discipline (Duckworth and Seligman, 2006), may be more likely to delay gratification (Silverman, 2003), or may have lower discount rates than young men (Warner and Pleeter, 2001). In this section we summarize the interventions in which gender differences in response to services and incentives have been observed. ${ }^{11}$

As discussed in the earlier section, the Quantum Opportunity Program worked remarkably for females but did quite poorly for males (Rodríguez-Planas, 2010). Similarly, Bernstein et al., 2009, also find heterogeneous effects by gender in their experimental evaluation of the Student Mentoring Program. In particular, they find that the impacts on girls were statistically significantly different from impacts on boys for two self-reported scales: Scholastic Efficacy and School Bonding, which measured academic performance; and Pro-social Behaviors, which

\footnotetext{
${ }^{10}$ In one of the two study districts, test score effects were large, there was evidence of positive spillovers to boys, and student school attendance increased in program schools. In the other district, attrition complicated estimation, but they could not reject the hypothesis that there were no program effect.

${ }^{11}$ To our knowledge, the only exception is Fryer, 2010, who has recently found that in an intervention involving financial incentives on input (in this case reading books), boys seem to gain more from the experiment than girls.
} 
measured non-cognitive skills, such as interpersonal relationships, personal responsibility, and community involvement. For boys, the impact on Pro-social Behaviors was negative and statistically significant (that is, treatment group boys had lower Pro-social Behaviors scores than those in the control group). For girls, the impact on Scholastic Efficacy and School Bonding was positive and statistically significant.

In terms of educational services, Anderson, 2008, shows that three well-known early childhood interventions (Abecedarian, Perry, and the Early Training Project) had substantial short- and long-term effects on girls but no effect on boys. Similarly, a number of public-sector training programs generated larger effects on women than men (Robert J. Lalonde, 1995). A related intervention, which allowed access to better communities (and schools), the Moving to Opportunity randomized evaluation of housing vouchers, likewise generated clear benefits for girls, with little or even adverse effects on boys (Jeffrey R. Kling, Jeffrey B. Leibman, and Lawrence F. Katz, 2007).

Within the literature on financial incentives, Dynarski, 2008, estimates larger effects of tuition aid on college completion for women in the United States, while Garibaldi et al., 2007, find that tuition affects the completion rates of women more than men in Italy. As mentioned earlier, in the study of the effects of merit awards on Israeli high-school students, Angrist and Lavy, 2010, find effects on girls only. Similarly, the randomized trial looking at cash payments for academic achievement among college freshman in Canada finds clear effects for females but no effect on males (Angrist et al., 2009). A more modest but still marked gender differential crops up in the response to randomly assigned vouchers for private secondary schools in Colombia (Angrist, et al., 2002). 


\section{Where to Go Next?}

While most of these studies analyze the effects of the interventions during or shortly after the students have been exposed to the program, the evidence on the medium- or longer-term impacts is very scarce. In addition, and probably because of the shorter-term focus, all of these studies look at educational outcomes as opposed to adult employment outcomes and wages. Indeed very few papers have a broader, multi-angle focus of the effects of the program on youths' lives, including college completion, employment outcomes, earnings, risky behaviors, and other measures of family life and physical and mental well-being. However, knowing the long-term impacts of these interventions is key to disentangle the following questions: Do the short-term changes generated by the intervention persist or do they quickly fade away? Do they translate into longer-term payoffs as measured by post-secondary schooling, employment, and earnings? Do they provide a better understanding of the observed gender differences in response to educational services and incentives?

As a consequence measuring impacts at different points in time that include a broad scope of life outcomes (including non-cognitive skills) arises as an increasingly main priority. Moreover, observing impacts over time will enable us to better understand the mechanisms through which different components of the program work. While follow-up survey data is extremely expensive, administrative long-term data ought to be cheaper, easier to access and with fewer measurement and response problems (although also more limited in the range of outcome information available).

Second, this paper highlights that heterogeneity matters and that evaluations ought to be designed such that sample sizes are large enough to identify for whom the program works, as this has important implication for future policy targeting. In particular, the underlying factors responsible for the observed gender differences in response to services and incentives constitute an important puzzle in this literature, especially when they are put within the context of the more 
broadly observed gender differences in the labor market, where a gender gap persist both in wages and in prospects for advancement (Francine D. Blau and Lawrence M. Kahn, 2000). There is a need for further studies using experimental designs to answer whether and how services and cash incentives work differently across genders. There is also a need to reconcile these findings with those on laboratory and field experiments on gender differences in risk, social and competition preferences (Croson and Gneezy, 2009). A possible future development is to use the population from the field evaluations to conduct laboratory experiments (as they may behave quite differently than the most commonly used agents for laboratory experiments: college students).

While heterogeneity analysis combined with economic theory and institutional knowledge may help disentangle the mechanisms through which programs work, to truly identify channels, evaluations ought to be designed to test alternative mechanisms across different groups so that knowledge on what works for whom and why is improved, as is currently and increasingly done in evaluations in developing countries (Duflo, Dupas, and Kremer, 2009; Abhijit Banerjee, Rukmini Banerji, Esther Duflo, and Stuti Khemani, 2008; Duflo, Kremer, and Robinson, 2009, among others). To the best of my knowledge, Angrist et al., 2009, are the only ones to analyze an experimental evaluation designed to improve academic performance assigning separate types of services to different treatment groups.

Fourth, in addition to having internal validity, it is important that evaluations also have external validity. The question that ought to be a priority when designing such interventions and their evaluation is what would happen if the program were implemented broadly among the (targeted) population—be it at-risk youths, academically low-performing children, minorities, etc. Too frequently the interventions are implemented among individuals who have expressed an interest in participating into the particular program, potentially leading to creaming-up effects and questioning the external validity of the evaluation results. The Quantum Opportunity 
Program is quite unique in its design as the eligible population were low-performing children from schools with high drop-out rates (regardless of whether they wanted to participate in this special program or not).

\section{REFERENCES}

Anderson, M., 2008. "Multiple Inference and Gender Differences in the Effects of Early Intervention: A Reevaluation of the Abecedarian, Perry Preschool, and Early Training Projects," Journal of the American Statistical Association, American Statistical Association, vol. 103(484), pages 1481-1495

Angrist, Joshua, Eric Bettinger, Erik Bloom, Beth King, and Michael Kremer. 2002. "Vouchers for Private Schooling in Colombia: Evidence from a Randomized Natural Experiment.” American Economic Review, 92(5): 1535-1558.

Angrist, Joshua, Eric Bettinger, and Michael Kremer. 2006. "Long-Term Educational Consequences of Secondary School Vouchers: Evidence from Administrative Records in Colombia." American Economic Review 96(3): 847-862.

Angrist, Joshua, Daniel Lang, and Philip Oreopoulos. 2009. "Incentives and Services for College Achievement: Evidence from a Randomized Trial.” American Economic Journal: Applied Economics.

Angrist, Joshua D., and Victor Lavy. 2009. "The Effect of High School Matriculation Awards: Evidence from Randomized Trials.” American Economic Review.

Aseltine, R. H., Dupre, M., \& Lamlein, P. 2000. "Mentoring as a drug prevention strategy: An evaluation of across ages.” Adolescent and Family Health, 1, 11-20.

Ash, Katie. 2008. "Promises of Money meant to heighten Student Motivation.” Education Week, February 13.

Ashworth, K., J. Hardman, et al. 2001. "Education Maintenance Allowance: The First Year, A Qualitative Evaluation". Research Report RR257, Department for Education and Employment.

Attanasio, Orazio, Emla Fitzsimons, Ana Gomez, Diana Lopez, Costas Meghir and Alice Mesnard. 2006. "Child education and work choices in the presence of a conditional cash transfer programme in rural Colombia.” Working Paper W06/13. London: Institute for Fiscal Studies.

Banerjee, Abhijit, Rukmini Banerji, Esther Duflo, and Stuti Khemani. 2008. "Pitfalls of Participatory Programs: Evidence from a randomized evaluation in education in India.” American Economic Journal: Economic Policy.

Banerjee, A., S. Cole, E. Duflo and L. Linden. 2007. "Remedying Education: Evidence from Two Randomized Experiments in India," Quarterly Journal of Economics, Vol. 122 (3), pp.1235-64.

Becker, Gary. 1964. "Human capital; a theoretical and empirical analysis, with special reference to education.” New York: Columbia University Press. 
Becker, Gary. 1968. “Crime and punishment: An economic approach.” Journal of Political Economy 76:169-217.

Bénabou Roland, and Jean Tirole. 2003. “Intrinsic and Extrinsic Motivation.” Review of Economic Studies 70, 489-520.

Bettinger, Eric P., and Bridget Terry Long. 2005. “Addressing the Needs of Under-Prepared Students in Higher Education: Does College Remediation Work?” National Bureau of Economic Research Working Paper 11325.

Behrman, Jere R., P. Sengupta, and P. Todd. 2000. "Final Report: The Impact of PROGRESA on Achievement Test Scores in the First year." Washington, DC: International Food Policy Research Institute, Food Consumption and Nutrition Division.

Bernstein, L., C. Rappaport, L. Olsho, D. Hunt, and M. Levin. 2009. "Impact Evaluation of the U.S. Department of Education's Student Mentoring Program.” National Center for Education Evaluation and Regional Assistance 2009-4047.

Bettinger E. and B. Long, 2009. "Addressing the Needs of Underprepared Students in Higher Education: Does College Remediation Work?," Journal of Human Resources, University of Wisconsin Press, vol. 44(3).

Bettinger, Eric \& Slonim, Robert, 2007. "Patience among children," Journal of Public Economics, Elsevier, vol. 91(1-2), pages 343-363, February.

Binder, M., P. T. Ganderton, et al. 2002. "Incentive Effects of New Mexico's Merit-Based State Scholarship Program: Who Responds and How?", unpublished manuscript.

Blau F. and L. Kahn, 2000. "Gender Differences in Pay," Journal of Economic Perspectives, American Economic Association, vol. 14(4), pages 75-99, Fall.

Bonner, Sarah E. S., Mark Young, and Reid Hastie. 1996. "Financial Incentives and Performance in Laboratory Tasks: The Effects of Task Type and Incentive Scheme Type,' Unpublished manuscript, University of Southern California Department of Accounting.

Carneiro, P., and J. Heckman, James J., 2003. "Human Capital Policy," IZA Discussion Papers 821, Institute for the Study of Labor (IZA).

Camerer, Colin, and Robin Hogarth. 1999. "The Effects of Financial Incentives in Experiments: A Review and Capital-Labor-Production Framework.” Journal of Risk and Uncertainty, 19:1-3; 7-42.

Cameron, J., K. M. Banko, et al. 2001. "Pervasive Negative Effects of Rewards on Intrinsic Motivation: The Myth Continues." The Behavior Analyst 24: 1-44.

Cameron, S., \& Heckman, J. 1993. The nonequivalence of high school equivalents. Journal of Labor Economics, 11(1), 1-47.

Chaloupka, F. J., and H. Wechsler. 1996. "Binge drinking in college: The impact of price.” Contemporary Economic Policy 14, no. 4:112-24.

Cornwell, Christopher, Kyung Hee Lee, and David B. Mustard. 2005. "The effects of meritbased financial aid on course enrollment, withdrawal, and completion in college.” Journal of Human Resources 40, no. 4:895-917.

Cornwell, Christopher, David B. Mustard, and Deepa J. Sridhar. 2006. “The Enrollment Effects of Merit-Based Financial Aid: Evidence from Georgia’s HOPE Program.” 
Journal of Labor Economics,24(4): 761-86.

Croson R. and U. Gneezy, 2009. “Gender Differences in Preferences.” Journal of Economic Literature 2009, 47:2, 1-27

Chaloupka, F., and H. Saffer. 1999. "The Demand for Illicit Drugs," Economic Inquiry, Oxford University Press, vol. 37(3), pages 401-11, July.

Cho, H., Hallfors, D., \& Sanchez, V. (2005). Evaluation of a high school peer group intervention for at-risk youth. Journal of Abnormal Child Psychology, 33, 363-374.

Cunha, F., Heckman, J. J., Lochner, L. J., and Masterov, D. V. 2006. Interpreting the evidence on life cycle skill formation. In E. A. Hanushek, \& F. Welch (Eds.), Handbook of the Economics of Education, chap. 12. Amsterdam: North-Holland, pp. $697\{812$.

Currie, Janet. 2001. "Early childhood education programs." Journal of Economic Perspectives 15, no. 2:213-38.

Currie, J., and D. Thomas. "Early Test Scores, Socioeconomic Status, School Quality and Future Outcomes," Research in Labor Economics, v 20, 2001, 103-132,

Deci, E. 1975. Intrinsic Motivation (New York: Plenum Press).

Deci, E., Koestner, R. and Ryan, R. 1999. "A Meta-Analytic Review of Experiments Examining the Effects of Extrinsic Rewards on Intrinsic Motivation”, Psychological Bulletin, 125 (6), 627-668.

Dearden, L., Emmerson, C., Frayne, C., and Meghir, C. 2005. "Education Subsidies and School Drop-Out Rates.” Institute for Fiscal Studies Working Paper 05/11.

Deming, D. and S. Dynarski. 2009. "Into college, out of poverty? Policies to increase the ostsecondary attainment of the poor”. NBER Working Paper 15387.

Dishion, T.J., McCord, J. and Poulin, F. 1999. "When interventions harm." American Psychologist, 54, 755-765.

Dishion, T.J., Spracklen, K.M., Andrews, D.W. 1996. "Deviancy training in male adolescent friendships.” Behavior Therapy, 27, 373-390.

Dodge, K. A., Dishion, T. J., and Lansford, J. E. (Eds.) 2006. Deviant peer influences in programs for youth: Problems and solutions. New York: Guilford.

DuBois, D.L., Holloway, B.E., Valentine, J.C. and Cooper, H. 2002. "Effectiveness of mentoring programs for youth: A meta-analytical review", American Journal of Community Psychology, 30 (2), 157-197.

Duckworth, Angela Lee, and Martin P. Seligman. 2006. "Self-Discipline Gives Girls the Edge: Gender in Self-Discipline, Grades, and Achievement Test Scores.” Journal of Educational Psychology 98(1): 198-208.

Duflo, Esther, Pascaline Dupas and Michael Kremer, 2009. “Additional Resources versus Organizational Changes in Education: Experimental Evidence from Kenya.” Mimeo, MIT, Department of Economics.

Duflo, Esther, Michael Kremer, and Jonathan Robinson, 2009. "Nudging Farmers to Utilize Fertilizer: Theory and Experimental Evidence from Kenya.” Mimeo, MIT, Department of Economics.

Dynarski, Susan. 2003. "Does Aid Matter? Measuring the Effect of Student Aid on College Attendance and Completion.” American Economic Review 93(1): 279-88.

Dynarski, Susan. 2008. "Building the Stock of College-Educated Labor." Journal of Human Resources, 43(3): 576-610. 
Dynarski, Mark, and Gleason, Philip. 2002. "How Can We Help? What We Have Learned From Recent Federal Dropout Prevention Evaluations.” Journal of Education for Students Placed at Risk, 7 (1): 43-69.

El País, 2009. “Chequera Contra el Fracaso Escolar.” Reportaje de J.A. Aunión, 14 October, 2009.

Eckstein, Zvi and K.I. Wolpin. 1999. "Why Youths Drop Out of High School: The Impact of Preferences, Opportunities, and Abilities.” Econometrica, 67(6): 1295-1340.

Finn, J. (1989). Withdrawing From School. Review of educational research, 59, 117-142.

Frey, B. S. 1994. "How Intrinsic Motivation Is Crowded Out and In.” Rationality \& Society, 6(3): 334-352.

Frey, B. and R. Jegen. 2000. "Motivation Crowding Theory: A Survey of Empirical Evidence," CESifo Working Paper Series 245, CESifo Group Munich.

Frey, B. S. and Oberholzer-Gee, F. 1997. "The costs of price incentives: An empirical analysis of motivation crowding-out.” American Economic Review, 87(4):746-755.

Fryer, Roland. 2010. "Financial Incentives and Student Achievement: Evidence from Randomized Trials.” Department of Economics, Harvard University Working Paper.

Garibaldi, Pietro, Francesco Giavazzi, Andrea Ichino, and Enrico Rettore. 2007. "College Cost and Time to Obtain a Degree: Evidence from Tuition Discontinuities.” NBER Working Paper 12863.

Gneezy, U. and Rustichini, A. 2000. “Pay Enough or Don’t Pay at All”, Quarterly Journal of Economics, 115 (3), 791-810.

Gibbons, R. 1997. "Incentives and Careers in Organizations”, in D. Kreps and K.Wallis (eds.) Advances in Economic Theory and Econometrics, Vol. II (Cambridge, U.K.: Cambridge University Press).

Green, L., Fry, A. F., and Myerson, J. 1994. Discounting of delayed rewards: A life span comparison. Psychological Science, 5, 33-36.

Greene, A. 1986. "Future Time Perspective in Adolescence: The present of things future revisited", Journal of Youth and Adolescence, 15: 99-113.

Grossman, J. B., Rhodes, J. E. 2002. "The test of time: Predictors and effects of duration in youth mentoring relationships.” American Journal of Community Psychology, 30, 199_ 219.

Grossman, J. B., and J. P. Tierney. 1998. "Does Mentoring Work? An Impact Study of the Big Brothers Big Sisters program,” Evaluation Review, 22(3), pp. 402-425.

Gruber, Jonathan. 2001. Risky Behavior Among Youth: An Economic Analysis. Chicago: University of Chicago Press.

Hanushek Eric. 2003. “The Failure of Input-Based Schooling Policies.” The Economic Journal, 113, F64-F98.

Hall, J. 2003. "Mentoring and Young People: A literature review.” SCRE Research Report 114. University of Glasgow.

Hahn, A. 1999. "Extending the Time of Learning," in Douglas J. Besharov, ed., America's Disconnected Youth, Washington, D.C.: Child Welfare League of America, Inc.

Hahn, A., T. Leavitt and P. Aaron. 1999. Evaluation of the Quantum Opportunities Program, Heller Graduate School, Center for Human Resources, Brandeis University, Waltham, Massachusetts. 
Heckman, James J., 2000. "Policies to foster human capital," Research in Economics, Elsevier, vol. 54(1), pages 3-56, March.

Heckman, James J \& Lochner, Lance \& Taber, Christopher, 1998. "Tax Policy and HumanCapital Formation," American Economic Review, vol. 88(2), pages 293-97, May.

Herrera, C., Grossman, J. B., Kauh, T. J., Feldman, A. F., \& McMaken, J. (with Jucovy, L. Z.). 2007. "Making a difference in schools: The big brothers big sisters school-based mentoring impact study.” Philadelphia, PA: Public/Private Ventures.

Hertwig, Ralph and Andreas Ortmann. 1998. "Experimental Practices in Economics: A Methodological Challenge for Psychologists,'” Behavioral and Brain Sciences.

Heyman J. and D. Ariely. 2004. "Effort for Payment: A Tale of Two Markets." Psychological Science, 15 (11) 787-793.

Holland J. and B. Skinner. 1961. "The Analysis of Self-Behavior: A Program of SelfInstruction”.

Holmlund Helena, and Olmo Silva. 2009. "Targeting Non-Cognitive Skills to Improve Cognitive Outcomes: Evidence from a Remedial Education Intervention.” IZA DP No. 4476.

James-Burdumy Susanne, Mark Dynarski and John Deke. 2008. “After-School Program Effects on Behavior: Results From the $21^{\text {st }}$ Century Community Learning Centers Program National Evaluation.” Economic Inquiry, Vol. 46, No. 1, January 2008, 13-18

Jacob, B. and Lefgren L. 2004. "Remedial Education and Student Achievement: A regression Discontinuity Analysis”, Review of Economics and Statistics, vol. 86, pp. 22644.

Jackson, C. K. 2007. “A Little Now for a Lot Later: A Look at a Texas Advanced Placement Incentive Program.” http://works.bepress.com/c_kirabo_jackson/1.

Jekielek, S.M., Moore, K.A., Hair, E.C. and Scarupa, H.J. 2002. Mentoring: A promising strategy for youth development. (Child Trends Research Brief.) Washington, DC: Child Trends.

Jenkins, G. Douglas, Jr., Atul Mitra, Nina Gupta, and Jason D. Shaw. 1998. “Are Financial Incentives Related to Performance? A Meta-Analytic Review of Empirical Research,’” Journal of Applied Psychology 83, 777-787.

Kane, Thomas J. 1998. "Savings Incentives for Higher Education." National Tax Journal, Vol. 51, No. 3, pp. 609-620.

Kane, Thomas J. 2007. "Evaluating the Impact of the DC Tuition Assistance Grant Program.” Journal of Human Resources.

Karcher, M.J. 2008. The Study of Mentoring in the Learning Environment (SMILE): A randomized study of the effectiveness of school-based mentoring. Prevention Science.

Kirby, K. N. 1997. "Bidding on the future: Evidence against normative discounting of delayed rewards.” Journal of Experimental Psychology: General 126, 54-

Kling J., J.Liebman, and L. Katz, 2007. "Experimental Analysis of Neighborhood Effects," Econometrica, Econometric Society, vol. 75(1), pages 83-119, 01.

Kohn, A. 1993. Punished by Rewards (New York: Plenum Press).

Kohn, Alfie. 1999. Punished by Rewards the Trouble with Gold Stars, Incentive Plans, A's, Praise, and Other Bribes. Bridgewater, NJ: Replica Books. 
Kremer, Michael, Edward Miguel, and Rebecca Thornton. 2008. "Incentives to Learn.” The Review of Economics and Statistics.

Krueger A., and D. Whitmore, 2001. "Would Smaller Classes Help Close the Black-White Achievement Gap?," Working Papers 830, Princeton University, Department of Economics, Industrial Relations Section..

Kruglanski, A., I. Friedman, and Zeevi. 1971. "The Effect of Extrinsic Incentives on Some Qualitative Aspects of Task Performance." Journal of Personality and Social Psychology 39: 608-617.

Laibson, David, 1997. "Golden Eggs and Hyperbolic Discounting," The Quarterly Journal of Economics, vol. 112(2), pages 443-77.

LaLonde, Robert J. 1995. “The Promise of U.S. Employment and Training Programs." Journal of Economic Perspectives, 9(2): 149-68.

Lazear, E. (2000), “Performance, Pay and Productivity”, American Economic Review, 90 (5), 1346-1361.

Lavy, Victor, and Analia Schlosser. 2005. "Targeted Remedial Education for Underperforming Teenagers: Costs and Benefits.” Journal of Labor Economics, 23(4): 839-74.

Lepper, M., D. Greene, et al. 1973. "Undermining Children's Interest with Extrinsic Rewards: A Test of the 'Overidentification Hypothesis." Journal of Personality and Social Psychology 28: 129-137.

Lepper, M., Greene, D. and Nisbett, R. 1973. “Undermining Children’s Interest with Extrinsic Rewards: A Test of the 'Overjustification Hypothesis”', Journal of Personality and Social Psychology, 28, 129-137.

Leslie, L. L., and Brinkman, P. T. 1988. The Economic Value of Higher Education. San Francisco: Jossey-Bass.

Leve, L., and Chamberlain, P. 2005. "Association with Delinquent Peers: Intervention Effects for Youth in the Juvenile Justice System." Journal of Abnormal Child Psychology, 33, 339-347.

Leuven, E., H. Oosterbeek, and B. van der Klaauw. 2003. "The Effect of Financial Rewards on Students' Achievement: Evidence from a Randomized Experiment.” CEPR Discussion Paper 3921.

Levitt, S. 1998. "Juvenile Crime and Punishment," Journal of Political Economy, University of Chicago Press, vol. 106(6), pages 1156-1185.

Levitt, S. and L. Lochner, 2001. "The Determinants of Juvenile Crime," NBER Chapters, in: Risky Behavior among Youths: An Economic Analysis, pages 327-374 National Bureau of Economic Research, Inc.

Machin, Steven, Sandra McNally, and Costas Meghir, 2004. "Improving Pupil Performance in English Secondary Schools: Excellence in Cities," Journal of the European Economic Association, MIT Press, vol. 2(2-3), pages 396-405, 04/05.

Machin, Steven, Sandra McNally, and Costas Meghir, 2007. "Resource and Standards in Urban Schools", IZA DP 2653.

McCord, J. 1978. “A thirty-year follow-up of treatment effects.” American Psychologist, 2, 284-289. 
McCord, J. 1992. "The Cambridge-Somerville Study: A pioneering longitudinalexperimental study of delinquency prevention.” In J. McCord \& R. E. Tremblay (Eds.), Preventing antisocial behavior: Interventions from birth through adolescence (pp. 196206). New York: Guilford Press.

Nurmi, J. 1991. "How Do Adolescents See Their Future? A review of the development of future orientation and planning", Developmental Review, 11:1-59.

Pacula, R.L.; Grossman, M; Chaloupka, F.J.; P. O’Malley; L.D. Johnston and M.C. Farrelly. 2001. "Marijuana and Youth” in Jonathan Gruber's An Economic Analysis of Risky Behavior Among Youths. University of Chicago Press.

Patterson, G.R., Dishion, T.J., Yoerger, K. 2000. "Adolescent growth in new forms of problem behavior: Macro- and micro-peer dynamics.” Prevention Science, 1, 3-13.

Pema, E. and S. Mehay. 2009. "The Effect of High School JROTC on Student Achievement, Educational Attainment, and Enlistment” Southern Economic Journal, 76(2), 533-552.

Rhodes, Jean. 1994. "Older and Wiser: Mentoring Relationships in Childhood and Adolescence," The Journal of primary prevention, v 14 n 3, Spring.

Rhodes, Jean E., Jean B. Grossman, and Nancy L. Resch. 2000. “Agents of Change: Pathways through Which Mentoring RelationshipsInfluence Adolescents' Academic Adjustment.” Child Development, November/December, Volume 71, Number 6, Pages 1662-1671.

Rhodes, Jean 2008. "Improving Youth Mentoring Interventions Through Research-based Practice.” American Journal Community Psychology, 41:35-42.

Rockoff J. 2009. "Field Experiments in Class Size from the Early Twentieth Century." Journal of Economic Perspectives, Volume 23, 4: 211-230.

Rodríguez-Planas, Núria. 2010. “Longer-term Impacts of Mentoring, Educational Services, and Incentives to Learn: Evidence from a Randomized Trial in the US”. IZA discussion paper No. 4754, February 2010 (revised version: June 2010).

Schochet, Peter, John Burghardt, and Sheena McConnell. 2008. "Does Job Corps Work? Impact Findings from the National Job Corps Study.” American Economic Review, 98:5, 1864-1886.

Schultz, T. Paul. 2004. "School Subsidies for the Poor: Evaluating the Mexican Progress Poverty Program.” Journal of Development Economics, 74(2): 199-250.

Scrivener S., D. Bloom, A. LeBlanc, C. Paxson, C. Rouse, and C. Sommo, J. Au, J. J. Teres, and S. Yeh. 2008. “A Good Start Two-Year Effects of a Freshmen Learning Community Program at Kingsborough Community College.

Scrivener, Susan, Michael J. Weiss, and Jedediah J. Teres. 2009. "More Guidance, Better Results? Three-Year Effects of an Enhanced Student Services Program at Two Community Colleges.” MDRC report.

Silverman, Irwin W. 2003. "Gender Differences in the Delay of Gratification: A MetaAnalysis.” Sex Roles, 49(9-10): 451-463.

Skinner B. 1953. Science and Human Behavior. New York: The Free Press.

The Analysis of Behavior: A Program for Self Instruction, with James G. Holland, 1961.

Smith, V., and J. Walker. 1993. "Monetary Rewards and Decision Cost in Experimental Economics," Economic Inquiry, Oxford University Press, vol. 31(2), pages 245-61,

Titmuss, Richard M. 1970. The Gift Relationship. London: Allen and Unwin. 
Titmuss, Richard M. 1971. The Gift Relationship: From Human Blood to Social Policy. New York: Pantheon.

Tolan P., D. Henry, M. Schoeny, A. Bass. 2008. "Mentoring Interventions to Affect Juvenile Delinquency and Associated Problems.” Campbell Systematic Reviews.

Warner, John T., and Saul Pleeter. 2001. "The Personal Discount Rate: Evidence from Military Downsizing Programs.” The American Economic Review, 91(1): 33-53.

Wilson, W. J. 1987. "The truly disadvantaged: The inner city, the underclass, and public policy.” Chicago: University of Chicago Press.

Wilson, T., Hull, J. and Johnson, J. 1981. “Awareness and Self-Perception: Verbal Reports on Internal States”, Journal of Personality and Social Psychology, 40, 53-71. 